\title{
An Empirical Investigation of Adopters' Perceptions Toward M-Commerce: The Case of Bulgarian University Students
}

\author{
Nora Milanova \\ Postgraduate Student, City College, International Faculty of the University of Sheffield, \\ Thessaloniki, Greece \\ Email:nmilanova@citycollege.sheffield.eu \\ Vaggelis Saprikis* \\ Assistant Professor, \\ Western Macedonia University of Applied Sciences, \\ Department of Business Administration, Kozani, Greece \\ Emails: saprikis@gmail.com \& saprikis@teiwm.gr
}

Received: 18 July 2018/ Revised: 27 September 2018/ Accepted: 1 October 2018/Published online: 31 October 2018

\begin{abstract}
Mobile commerce (m-commerce) is a fact. Nowadays, numerous transactions take place via mobile devices. At the same time, m-commerce is considered as one of the fastest growing subgroups of e-commerce. Characteristically, it is estimated that about $45 \%$ of mobile users have made at least one purchase via a wireless hand-held device. Therefore, it plays and will continue to play a vital role in the global economy. The aim of this research paper is to investigate the perceptions of mobile commerce users focusing on Bulgarian University students. Specifically, it intends to reveal the perceived advantages and disadvantages of $\mathrm{m}$-commerce, the factors that motivate students to make online transactions via a hand-held device, as well as the issues that hinder them from doing so more often. The paper is expected to provide tangible results to both academia and the industry about a developing economy.
\end{abstract}

JEL classification: M15, M390

Keywords: mobile commerce, m-commerce intention, mobile shopping adoption.

\section{INTRODUCTION}

The technological advancement during the last decades has definitely left its impact on humanity and our way of living. Various aspects of our daily life have dramatically changed due to the technology and innovations (Patil, 2017). Because of these technological advancements and Information Technology (IT) infrastructure, even more people use more and more IT solutions. As a consequence, companies are increasingly reaching out to customers through newer channels such as electronic commerce (e-commerce) and more recently mobile commerce (m-commerce) (Khare \& Sadachar, 2014; Liang \& Wei, 2004; Maity \& Dass, 2014). Mobile commerce is related 
to activities connected to buying or generally making transactions via mobile devices, including using mobile applications and adapted websites to shop mainly via a smartphone, tablet, netbook or notebook (Ciprian \& Vlad, 2016; Hillman \& Neustaedter, 2017).

Since the smartphone invasion into our lives, people have been inseparable from these technologies (Narang \& Arora, 2016). People carry them and use the wireless network connection for mobile banking, browsing information, mobile advertising, entertainment, trading, social networking, and of course shopping (Gao et al., 2014; Hsi-Peng \& Su, 2009; San-Martín et al., 2016). Mobile phones are even assumed to be inseparable from the purchasing process, with 9 out of 10 consumers looking for a product or service on a mobile device and $45 \%$ of them shopping with their wireless hand-held devices (IAB, 2014). That is the reason why many retail companies with different product categories have changed their strategies and provided mobileoptimized sites or developed applications which are comfortable and user-friendly (Ratcliff, 2015). Moreover, they are capable of personalizing the provided services and the search of each customer, getting every level of detail of his/ her interest, with the aim to lure him/her into a purchase (Georgiadis \& Stergiopoulou, 2008).

The advantages of $\mathrm{m}$-commerce have recently led to a trend which shows that $\mathrm{m}$-commerce is starting to outgrow e-commerce. One of the main reasons for this recent change has been the growing popularity of smartphone usage (Chang et al., 2014) resulting from the inexpensiveness of mobile smartphones, better mobile broadband connectivity and the opportunity for people to access goods and services at any time from any place (OECD, 2013). Thus, it is expected that m-commerce will soon become the mainstream and by 2020 it will be $45 \%$ of the whole e-commerce in the USA (Meola, 2016). However, there are many factors that slow the development of m-commerce and detain its full success. Among them are the small screen size, the slow speed of mobile connection (Meola, 2016), and also trust and security issues of the users (Eastin et al., 2016). Other factors that could negatively affect the m-commerce adoption are social factors or demographic characteristics, such as age, income and level of education (Saritas et al., 2016). Obviously, the development of m-commerce is somewhat different in every country (Zhang et al., 2012) as these factors exert dissimilar influence around the globe. According to Yadav et al. (2016), in order to boost m-commerce, it is substantial to have a greater understanding of the factors that prevent mobile phone users from pursuing the various $\mathrm{m}$-commerce activities.

Regarding Bulgaria, statistics have mentioned that the smartphone usage in the country went up from $33 \%$ to $48 \%$, while the computer usage increased by only $1 \%$ (from $69 \%$ to $70 \%$ ) in the 2014-2016 period (Statista, 2016). The mobile connectivity is getting better and faster with three main telecommunication enterprises, Telekom Austria's M-Tel, Telenor's local unit, and the incumbent Vivacom, providing competitive services (Lancaster, 2016). Furthermore, the proportion of formal university graduates using mobile devices to access the internet on the move has increased from $41 \%$ in 2013 to $71 \%$ in 2016 (a 30\% increase in about 3 years) (Eurostat, 2016). Individuals in Bulgaria are starting to adopt mobile shopping practices and buy more goods and services via their mobile devices as a preferred method, even if it is at a slower pace compared to the rest of the European countries (Tairov, 2014). This could be because commercial banks in Bulgaria operate in an environment that is full of challenges stemming from changes in regulations and accounting rules which interfere with mobile payments and thus the $\mathrm{m}$-commerce development (Grigorova, 2015). Nevertheless, m-commerce transactions in Eastern European countries, including Bulgaria, increased considerably by $68.7 \%$ in 2015 compared to the previous year (Ecommerce News Europe, 2016). On the contrary, up to the end of 2016, $89 \%$ of online shoppers in Bulgaria shopped online via a desktop computer; only 5\% and 3\% of them bought via a smartphone or a tablet respectively. Based on the aforementioned fact as well as a review of the literature on mobile shopping behavior, a significant gap has been identified as no empirical study has been undertaken to analyze the current situation and future intentions as regards $\mathrm{m}$-shopping in Bulgaria. Clearly, this new phenomenon is worth closer examination and research for academic 
and public purposes. Therefore, the aim of this research paper is to reveal m-commerce adopters' perceptions in the country and provide vital information to the academic community and the IT industry focused on university students.

\section{LITERATURE REVIEW}

The differentiation of $\mathrm{m}$-commerce from other channels of trade is a debatable topic (Jimenez et al., 2016). According to numerous past studies, m-commerce is often perceived as an extension of e-commerce with the difference that transactions are made through a hand-held device and via a wireless connection (Chong, 2013). Others believe that m-commerce is not only an extension of e-commerce but rather it is a new innovative business channel which has overcome the barriers of location and time and has extremely changed the way in which people interact with the surrounding environment (Faqih \& Jaradat, 2015). Furthermore, Zhang et al. (2012) argue that m-commerce has the advantages of "instantaneity, ubiquity, localization, personalization and identification" (p. 1902) and is a market with great potential. In fact, the number of mobile phone subscribers is overtaking the number of internet users in some countries and at the beginning of 2014, the number of global users of mobile phones has outgrown the number of global desktop computer users (Chaffey, 2017). Moreover, m-commerce applications are generating significant profits (Bhatty, 2015).

Since mobile commerce has been increasing at a fast pace for the last few years, it is highly important to examine specific factors, such as technological and consumer characteristics which can predict and affect directly and indirectly the adoption of this new way of retail. By a further analysis of these characteristics, it would be much easier to understand the differences in the consumer adoption of mobile shopping (Yang, 2012). The success of mobile shopping depends on consumers' willingness to adopt the new technology and change their previous shopping habits (Shang \& Wu, 2017). That is why it is highly important to find out how consumers' attitudes and beliefs affect their use of $\mathrm{m}$-commerce services and identify the factors that influence the adoption of mobile shopping ( $\mathrm{Lu} \& \mathrm{Su}, 2009$ ).

\section{Factors Considered Important for the M-Commerce Adoption}

Previous research connected to m-commerce users and adoption has been based on numerous theories such as the Technology Acceptance Model (TAM) and the Diffusion of Innovation (DOI) model (Chong, 2013). Furthermore, the Theory of Planned Behavior (TPB), which extends the Theory of Reasoned Action (TRA), also played its part in many studies on m-commerce (Zhang et al., 2012). All of them have a great value in the understanding of m-commerce adoption but they also have their limitations. Zhang et al. (2012) state that TAM concentrates on internal perceptions, TPB implies external influences and the Innovation Diffusion Theory (IDT) focuses on innovation characteristics.

Most of the adopters, whether they are early adopters or find the benefits of mobile commerce at a later point, seek to find a positive outcome and the usefulness of buying via a hand-held device. This factor is called performance expectancy by Venkatesh et al. (2003). It generalizes the factors perceived usefulness, extrinsic motivation, job-fit, relative advantage, and outcome expectations (p. 447). Furthermore, when consumers are confident that mobile shopping is useful, they are positive about the mobile shopping adoption (Zarmpou et al., 2010).

In the UTAUT (Unified Theory of Acceptance and Use of Technology) theory, the variables such as perceived ease of use, complexity and ease of use are also summarized under one factor - effort expectancy (Venkatesh et al., 2003). In a study, Yang (2012) stated that the perception of ease of use is extremely close in meaning to perceived usefulness and should not be considered 
separately. Other research argues for the opposite and states that the perceived ease of use is defined as the degree to which an individual believes that the use of technology would be free of effort or would require a less effort (Davis, 1989). A more recent study by Agrebia and Jallaisb (2015) reveals that the ease of use was found insignificant for both previous purchasers and non-purchasers when making the decision to adopt $\mathrm{m}$-commerce. This might be explained by the fact that many people are accustomed to using smartphones for e-mails, online search, etc., and are experienced enough. Even though Agrebia and Jallaisb (2015) found that perceived ease of use is insignificant for the adoption of m-commerce, their study was not conducted in the context of Bulgaria, where the conditions are different.

In a study, Yang (2012) points out that a very important factor for the adoption of m-commerce is the perceived behavioral control. It refers to the belief that an individual is capable of performing something which is in mind and is connected to previous experience and perceptions (San-Martín et al., 2016). This belief is very important when adopting a new technological trend as it includes the knowledge and technological infrastructure to make mobile shopping transactions (mobile internet connection, speed, data service availability and data processing capability). The perceived behavioral control can be connected to the ease of access. Lu and $\mathrm{Su}$ (2009) see the ease of access as a significant factor that has an influence on the adoption of m-commerce. It refers to the degree to which a customer believes that accessing the internet via a mobile phone will be free of effort.

Users often gather information from and imitate actions of people who are in their surroundings and who are significant to them (San-Martín et al., 2016). When a user is a part of a particular social group, he/she is inevitably affected by others' opinions and experiences and usually, the individual intends to comply with the social influences (Venkatesh et al., 2003). That is why the subjective norm has a direct and positive effect on the intention to do mobile shopping (Yang, 2012). Furthermore, when it comes to decision making and adoption of any kind of new technology, the attitude toward the technology has an important role. The attitude is explained as the consumers' positive or negative feeling about executing a particular action (Yang, 2012). When it comes to purchasing items via a smartphone or a tablet, perceived enjoyment really reflects the attitude of mobile shopping users. It is referred to as the belief that the use of technology is pleasure and fun (Agrebia \& Jallaisb, 2015). As a result, Yang (2012) states that the perceived enjoyment is related to the attitude toward doing mobile shopping in a positive way and the attitude will have a direct and positive effect on the users' intentions to adopt mobile shopping practices. In addition, another factor affecting the attitude of consumers when making a purchase decision online is anxiety. It refers to negative emotions in the cognitive process and has a significantly negative influence on information systems adoption ( $\mathrm{Lu} \& \mathrm{Su}, 2009)$. A factor that also has an effect on the emotional and cognitive process of mobile purchase is satisfaction. According to Dužević et al. (2016), five variables are important for the satisfaction of m-commerce users - convenience, reliability, price, visibility, and functionality. Most often, satisfaction has an influence after the first use of mobile commerce channels and can be a positive factor for future purchases (Agrebia \& Jallaisb, 2015). Another factor with significance in the studies on the m-commerce adoption is the level of experience of use, also called familiarity (Zarmpou et al., 2010). It has a tremendous impact on the adoption of mobile shopping practices and is explained as the consumer experience in using a new technology for a specific continued period (Yang, 2012).

However, Min et al. (2008) believe that trust is one of the most important factors in the studies on both e-commerce and marketing and earning users' trust is critical for the success of m-commerce. Trust is definitely a factor that should not be ignored when talking about the m-commerce adoption (Zhang et al., 2012). According to a study by Nassuora (2013), perceived trust and perceived privacy have a positive impact on the decision to buy via a hand-held device and if there is trust in the channels of purchase and the technology, then transactions will be more likely to take place. Other important factors that encourage users to adopt m-commerce are content quality, system quality, support and personalization factors (Dužević et al., 2016). 
As every user has his/her own characteristics and differences in the perception of technology, the process of adoption of mobile shopping practices might really differ. Yang (2012) believes that demographic differences are not that significant when trying to understand the behavioral intention to purchase a product or service. On the other hand, other research has proven that the demographic profiles of consumers are important predictors of the m-commerce adoption. The most significant demographic factor is age followed by education. Both of them have been proved to have an influence on the mobile shopping adoption. Younger and higher educated consumers have a positive attitude to mobile shopping, while gender was found to be of nonsignificant relevance for the adoption of m-commerce (Chong, 2013). Later, a study by Faqih and Jaradat (2015) finds gender as a non-significant factor in the adoption of m-commerce. They proved that both genders are equally comfortable about using the features of mobile devices and m-commerce. However, Chen et al. (2015) state that gender differences influence the attitude toward online shopping; men and women have different perceptions of risk. The study by Faqih and Jaradat (2015) contributes to the literature so far as it explains that there is a great difference in the adoption of m-commerce when it comes to cultural values and traditions. Even though it was proven that the better educated a person is, the more likely he/she is to use the internet (Rhee and Kim, 2004), not enough research has been done on the connection between education and technology adoption. A special survey which was conducted in 2013 by the Pew Research Center proved that the biggest group of tablet owners is the group of graduating people or those who have already obtained a higher education level degree (Zickuhr, 2013). The Pew Research Center has proven the same for smartphone ownership where the biggest group using and owning a smartphone is also higher educated people (Anderson, 2015). Chong (2013) also states that educational level is positively related to the usage of $\mathrm{m}$-commerce. Thus, it is highly important to fill this gap in the academic research on the topic and investigate Bulgarian higher education students and their response to m-commerce.

An interesting thing to follow up when it comes to the adoption of mobile commerce processes is to see what happens when users are already using mobile devices for online purchases. According to Wang et al. (2015), when customers adopt m-commerce, their order size and order rate increase. Also, as customers continue to find value in mobile shopping and increase their mobile shopping occurrences, their spending and likelihood of making a purchase again will increase. As for the products or services they purchase, Wang et al. (2015) state that customers usually purchase products that they have bought previously or products from brands that they are highly loyal to.

Based on the aforementioned literature review, the demographics and the activity features of mobile adopters among Bulgarian university students are to be examined. Specifically, possible connections and differences between these characteristics and advantages/disadvantages, perceived benefits and attitudes toward $\mathrm{m}$-commerce will be investigated. Therefore, the research questions in the paper are as follows:

1. What are the demographic characteristics of m-commerce adopters?

2. Are there any relationships between age and the period of m-commerce use, monthly $\mathrm{m}$-amounts spent and the number of annual $\mathrm{m}$-transactions?

3. What are the preferred products and services for m-shopping among Bulgarian university students?

4. Are there any differences in perceived advantages and disadvantages of $m$-commerce among Bulgarian university students based on their demographics and mobile activity?

5. What are the perceived benefits of m-commerce among Bulgarian university students?

6. Are there any connections between perceived benefits and the number of $\mathrm{m}$-transactions among Bulgarian university students?

7. Are there any differences in m-commerce attitudes among Bulgarian university students based on their demographics? 


\section{RESEARCH METHOD}

The research is primarily descriptive in nature, as apart from descriptive statistics, only simple statistics, namely chi-square and t-tests, were used in order to statistically examine m-commerce adopters' perceptions. Data was collected by means of an electronic questionnaire administered from 10.07.2017 to 13.08.2017. The sample consists of Bulgarian higher education students with different specializations and spheres of expertise for the purposes of comprehensiveness. The respondents are also diverse in terms of gender and age. Even though the sample is not a good representative group of the whole Bulgarian population, the students have the highest technology adoption rate (Hitt \& Frei, 2002), thus, the responses were expected to be more numerous and more valuable. Furthermore, the selection of student respondents for primary research has been successfully used in many studies (e.g., Saprikis, 2013; Shead et al., 2012).

The study used a single random sample and the first part of the questionnaire aimed to identify the frequency of use of m-commerce, the number of transactions made, the main products and services purchased and the amounts of money spent with a smartphone/tablet. Six of the questions were designed to help identify the advantages and disadvantages that respondents see in $\mathrm{m}$-commerce. The variables used were Time, Cost, Access, Level of Complexity, Communication and Social Contact. A question was developed to analyze the intentions to buy via a mobile phone in the future. The research questions were mainly connected to the respondents' perceptions of different factors that determine $\mathrm{m}$-commerce. These questions were presented with the 5-point Likert scale. Table 1 summarizes the "perceptions" questionnaire items and the scientific sources that they are based on. All research items were adopted from the sources mentioned in Table 1.

Table 1

Scale items of the "perceptions" questions

\begin{tabular}{|c|c|c|}
\hline Variable & Scale item statements & Source \\
\hline \multirow{3}{*}{ Trust } & I feel using $\mathrm{m}$-services in monetary transaction is safe. & \multirow{3}{*}{$\begin{array}{l}\text { Zarmpou et al., } \\
2012\end{array}$} \\
\hline & I feel my personal data are in confidence while using m-service. & \\
\hline & I feel the terms of use are strictly followed while using m-services. & \\
\hline \multirow{2}{*}{ Attitude } & Shopping by mobile phone is a good idea. & \multirow{2}{*}{ Yang, 2010} \\
\hline & I am positive about mobile shopping. & \\
\hline \multirow{2}{*}{ Subjective norm } & $\begin{array}{l}\text { I would shop by phone because of the proportion of my friends who } \\
\text { do mobile shopping. }\end{array}$ & \multirow{2}{*}{ Yang, 2012} \\
\hline & $\begin{array}{l}\text { People who are important to me think that I should use mobile } \\
\text { shopping. }\end{array}$ & \\
\hline \multirow{7}{*}{$\begin{array}{l}\text { Perceived benefits } \\
\text { of mobile } \\
\text { commerce }\end{array}$} & It is useful as it provides information based on location. & \multirow{7}{*}{ Lee \& Lee, 2007} \\
\hline & I can use it anywhere. & \\
\hline & I can use it anytime. & \\
\hline & It is convenient. & \\
\hline & It is enjoyable. & \\
\hline & It provides me with a rapid response. & \\
\hline & It is useful as it provides information based on location. & \\
\hline
\end{tabular}

The last part of the questionnaire gathers the demographic information needed for the study. The questionnaire contained demographic measures for age, gender, educational level and educational background. The fields of education were based on the research entitled "SCED 
Fields of Education and Training 2013 (ISCED-F 2013)" from UNESCO Institute for Statistics, which categorizes them in ten main groups of education and training fields.

The whole sample consists of 400 responses. 390 students stated that they own an internetenabled hand-held device (smartphone, tablet) for accessing the internet. More than 1/4 of them, who own a mobile device, stated that they do not take part in m-commerce, however, around half of them intend to become part of mobile shopping in a near future. On the other hand, 287 $(73.6 \%)$ students declared that they use their smartphones/tablets for online shopping and they will be used in the research results (research sample).

\section{RESULTS}

This section presents the results regarding $\mathrm{m}$-commerce adopters. It includes their demographic characteristics and their m-commerce habits and preferred products and services. Furthermore, their perceived advantages and disadvantages along with their perceived benefits and attitude toward $\mathrm{m}$-commerce are presented based on their demographics and m-commerce activity.

\subsection{Demographic Characteristics of M-Commerce Adopters}

Female adopters account for $65.85 \%$ of the total sample, whereas males were the rest, i.e. $34.15 \%$. Specifically, the greatest part of the adopters was female postgraduate students $(39.37 \%)$ and the smallest part was male undergraduates (13.24\%) (Table 2).

Table 2

Gender and education level

\begin{tabular}{|c|c|c|c|c|}
\hline \multirow{2}{*}{ Gender } & \multicolumn{2}{|c|}{ Undergraduate students } & \multicolumn{2}{|c|}{ Postgraduate students } \\
\hline & No & $\%$ & No & $\%$ \\
\hline Male & 38 & $13.24 \%$ & 76 & $26.48 \%$ \\
\hline Female & 60 & $20.91 \%$ & 113 & $39.37 \%$ \\
\hline
\end{tabular}

Overall, the age of the respondents ranged from 18 to 28 or more. The group with most respondents is 25 - to 27 -year-olds (30.31\%), followed by 23 - to 24 -year-olds (26.83\%) (Figure 1).

Figure 1

Age of respondents

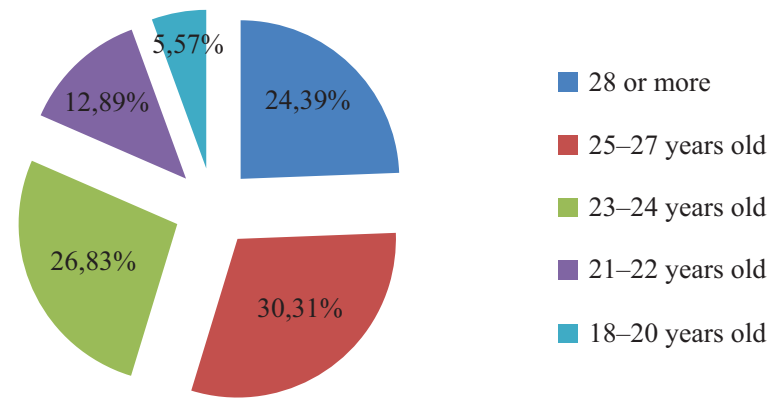

Most of the respondents of the survey were women, a bit above $65 \%$. When it comes to age compared to gender of the respondents, it became clear that a majority of females in the survey are from 23 to 27 years old; similarly, most of males are aged from 25 to 27 years.

The education level of the respondents who have adopted $\mathrm{m}$-commerce is mostly postgraduate. The participants in the survey had various educational backgrounds and qualifications. $41.1 \%$ 
of the respondents study business, administration and law followed by Information and Communication Technologies (ICTs) (11.5\%) and engineering, manufacturing and construction $(9.8 \%)$ (Table 3).

Table 3

Educational background

\begin{tabular}{lccc}
\multicolumn{1}{c}{ Educational background } & \multicolumn{2}{c}{ Gender } & Total \\
\hline Business, administration and law & Male & Female & $41.1 \%$ \\
\hline Other & $13.6 \%$ & $27.5 \%$ & $12.5 \%$ \\
\hline Information and communication technologies & $4.2 \%$ & $8.4 \%$ & $11.5 \%$ \\
\hline Engineering, manufacturing and construction & $6.3 \%$ & $5.2 \%$ & $9.8 \%$ \\
\hline Arts and humanities & $3.8 \%$ & $5.9 \%$ & $5.9 \%$ \\
\hline Social sciences, journalism and information & $2.4 \%$ & $3.5 \%$ & $5.6 \%$ \\
\hline Education & $1.7 \%$ & $3.8 \%$ & $4.5 \%$ \\
\hline Natural sciences, mathematics and statistics & $2.1 \%$ & $2.4 \%$ & $3.8 \%$ \\
\hline Health and welfare & $2.8 \%$ & $1 \%$ & $3.8 \%$ \\
\hline Services & $2.1 \%$ & $1.7 \%$ & $1 \%$ \\
\hline Agriculture, forestry, fisheries and veterinary & $0.3 \%$ & $0.7 \%$ & $0.3 \%$ \\
\hline & $0.3 \%$ & $\mathbf{1 1 4}$ & $\mathbf{1 7 3}$ \\
\hline
\end{tabular}

\subsection{Age and M-Commerce Habits}

The respondents of the survey have used m-commerce services for different periods of time. Most of the students have used their hand-held devices to shop online for 1-2 years $(37.6 \%)$ and $25.1 \%$ of the students have used them for $3-4$ years. Furthermore, $5.9 \%$ of all men and $10.5 \%$ of the women are new m-commerce adopters. However, no statistically significant dependency on both variables - gender and the period of use - was found $(p>0.05)$.

When it comes to money spent on m-commerce, most of the students spent $€ 30-59$ during the last year. This is normal as many of the students do not have stable incomes and cannot afford to spend much money online. After analyzing the variables: gender and money spent during the last month, it becomes clear that $23 \%$ of all men and $30.3 \%$ of all women spent less than $€ 30$. In contrast, the total percentage of people who spent more than $€ 60$ is exactly $15 \%$. As the p value is greater than 0.05 ( $p>0.05)$, it can be stated that there is no relationship between gender and money spent during the last month, and the two variables are independent from one another (Table 4). 
Table 4

Habits and preferences

\begin{tabular}{|c|c|c|c|c|c|}
\hline \multirow{2}{*}{ Adopters' habits and preferences } & \multicolumn{2}{|c|}{ Male } & \multicolumn{2}{|c|}{ Female } & \multirow{2}{*}{ Chi-square test } \\
\hline & $\mathbf{N}$ & $\%$ & $\mathbf{N}$ & $\%$ & \\
\hline
\end{tabular}

\section{Period of use}

Less than a year

1-2 years

$\begin{array}{rrr}17 & 5.90 \% & 30 \\ 41 & 14.30 \% & 67 \\ 27 & 9.40 \% & 45 \\ 29 & 10.10 \% & 3\end{array}$

3-4 years

$\begin{array}{rrr}17 & 5.90 \% & 30 \\ 41 & 14.30 \% & 67 \\ 27 & 9.40 \% & 45 \\ 29 & 10.10 \% & 3\end{array}$

27

More than 4 years

29

$\begin{array}{llc}30 & 10.50 \% & \mathrm{df}=3 \\ 67 & 23.30 \% & \mathrm{p}=0.495 \\ 45 & 15.70 \% & \\ 31 & 10.80 \% & \end{array}$

$10.80 \%$

Money spent last month

\begin{tabular}{lrrrrc} 
Less than $€ 30$ & 66 & $23.00 \%$ & 87 & $30.30 \%$ & $\mathrm{df}=4$ \\
$€ 30-€ 59$ & 32 & $11.10 \%$ & 59 & $20.60 \%$ & $\mathrm{p}=0.749$ \\
$€ 60-€ 99$ & 8 & $2.80 \%$ & 14 & $4.90 \%$ & \\
$€ 100-€ 150$ & 4 & $1.40 \%$ & 5 & $1.70 \%$ \\
\hline Over $€ 150$ & 4 & $1.40 \%$ & 8 & $2.80 \%$
\end{tabular}

\begin{tabular}{lrrrrr} 
Number of m-transactions (past year) & & & & \\
\hline None & 3 & $1.00 \%$ & 9 & $3.10 \%$ & \\
\hline $1-5$ & 53 & $18.50 \%$ & 61 & $21.30 \%$ & $\mathrm{df}=5$ \\
\hline $6-10$ & 27 & $9.40 \%$ & 50 & $17.40 \%$ & $\mathrm{p}=0.275$ \\
\hline $11-25$ & 16 & $5.60 \%$ & 33 & $11.50 \%$ & \\
\hline $26-50$ & 7 & $2.40 \%$ & 13 & $4.50 \%$ & \\
\hline Over 50 & 8 & $2.80 \%$ & 7 & $2.40 \%$
\end{tabular}

Another interesting result is that students made from 1 to 5 transactions via a hand-held device during the last year (18.5\% of males and $21.3 \%$ of females). $26.8 \%$ of all students made between 6 and 10 transactions and only $5.2 \%$ of them made over 50 purchases. Only 12 of the mobile commerce adopters did not buy anything with their hand-held device during the last 12 months. Analogically, no relationship between gender and number of online transactions in the last year was estimated. Furthermore, the same analyses were done between the level of education and the variables: period of use, money spent in the last month and number of online transactions during the last year, and no connection or dependencies were observed.

Unlike gender and level of education, age is connected to the total amount that is spent online as with age people tend to get more income and become more experienced in mobile shopping. This can be proven by the fact that mostly students above 25 years old tend to spend more than $€ 60$ online a month. This close connection between age and money spent on mobile commerce is directly proportional.

\subsection{Preferred Products and Services for M-Shopping}

This study confirms the findings from past research and concludes that respondents buy mostly clothing, apparel and accessories with their mobile devices. Specifically, almost $30 \%$ of the 
respondents who buy clothes were male and above $70 \%$ were female mainly at the age of $23-24$. Other categories of products and services chosen by the respondents as preferred for mobile shopping are travel services, vouchers, online coupons and entertainment services (Table 5).

Table 5

Products and services purchased

\begin{tabular}{|c|c|}
\hline Products and services purchased & Percent \\
\hline Clothing, apparel and accessories & $22 \%$ \\
\hline Travel services & $12.90 \%$ \\
\hline Books, music, video & $11.30 \%$ \\
\hline Vouchers, online coupons & $11.10 \%$ \\
\hline Computer and consumer electronics & $8.50 \%$ \\
\hline Entertainment services & $8.10 \%$ \\
\hline Food and beverages & $7 \%$ \\
\hline Toys and hobby & $6.30 \%$ \\
\hline Health and personal care & $5.40 \%$ \\
\hline Auto and parts & $3.90 \%$ \\
\hline Furniture and home furnishing & $2.40 \%$ \\
\hline Insurance, financial services & $1.10 \%$ \\
\hline
\end{tabular}

\subsection{Perceived Advantages and Disadvantages of M-Commerce Across Demographic Characteristics and Mobile Activity}

With the help of the 5-point Likert scale and the independent sample T-test, the research examined the perceptions of the students on six main variables which can determine some of the advantages or disadvantages of m-commerce. By analyzing the mean and the standard deviation, we can approximately estimate with $95 \%$ accuracy the answers chosen by the respondents (Table 6). 
Table 6

Perceived advantages and disadvantages of $\mathrm{m}$-commerce

\begin{tabular}{|c|c|c|c|c|c|c|}
\hline Disadvantage/advantage & Gender & $\mathbf{N}$ & Mean & Std. deviation & Std. err. mean & t-test value \\
\hline \multirow{2}{*}{ Time-consuming or time-efficient } & Male & 114 & 4.24 & 0.97 & 0.09 & \multirow{2}{*}{1.83} \\
\hline & Female & 173 & 4.01 & 1.05 & 0.08 & \\
\hline \multirow{2}{*}{ Expensive or inexpensive } & Male & 114 & 3.86 & 0.84 & 0.08 & \multirow{2}{*}{2.12} \\
\hline & Female & 173 & 3.64 & 0.90 & 0.07 & \\
\hline \multirow{2}{*}{ Slow access or immediate access } & Male & 114 & 4.25 & 0.79 & 0.07 & \multirow{2}{*}{1.27} \\
\hline & Female & 173 & 4.12 & 0.89 & 0.07 & \\
\hline \multirow{2}{*}{ Complex or easy to use } & Male & 114 & 3.97 & 0.81 & 0.08 & \multirow{2}{*}{0.02} \\
\hline & Female & 173 & 3.97 & 0.99 & 0.08 & \\
\hline \multirow{2}{*}{$\begin{array}{l}\text { Ineffective communication } \\
\text { or effective communication }\end{array}$} & Male & 114 & 4.01 & 0.86 & 0.08 & \multirow{2}{*}{0.13} \\
\hline & Female & 173 & 3.99 & 0.94 & 0.07 & \\
\hline \multirow{2}{*}{$\begin{array}{l}\text { Lack of social contact } \\
\text { or intensive social contact }\end{array}$} & Male & 114 & 3.19 & 1.14 & 0.11 & \multirow{2}{*}{-1.11} \\
\hline & Female & 173 & 3.36 & 1.30 & 0.10 & \\
\hline
\end{tabular}

A majority of the male and female students in the sample believes that m-commerce is time-efficient. Overall, no dependency between gender and the perceptions of time was found. Furthermore, as males, females also believe that access to $\mathrm{m}$-commerce is immediate and there is no statistically significant difference between the opinions about accessibility of m-commerce. To continue, communication with sellers and businesses is important when shopping online, as it leads to satisfaction and more future transactions. The analyses point out that male and female students in Bulgaria are mostly fond of communication when being part of $\mathrm{m}$-commerce and see it as effective. On the contrary, it was proven that there is a statistically significant difference between the perceptions of males and females when it comes to the cost of $\mathrm{m}$-commerce. Women perceive it as a more expensive service than men, thus, cost is seen as a disadvantage. Another disadvantage according to the results can undisputedly be the lack of social contact in m-commerce.

Furthermore, by applying Analyses of Variance (ANOVAs), we compared the aforementioned advantages/disadvantages of $\mathrm{m}$-commerce with the number of $\mathrm{m}$-transactions. This analysis intended to reveal if the level of m-transactions did impact on the perceived advantages/ disadvantages. The results showed that none of the aforementioned was statistically influenced by the number of m-transactions.

ANOVAs were also conducted with the aim to compare the aforementioned advantages/ disadvantages of $\mathrm{m}$-commerce with the period of $\mathrm{m}$-commerce use and the money spent on $\mathrm{m}$-commerce during the last month. The results showed no statistically differences either.

\subsection{Perceived Benefits of M-Commerce}

Table 7 presents seven statements which aim to help evaluate the students' opinion about the real benefits from m-commerce. As all the mean scores for the questions are more than 3.9, the respondents believe that the above variables are an incentive to use m-commerce. Indeed, the stronger motivators for the students are the fact that they can use m-commerce anywhere they are and at any time. They claim its convenience and the enjoyment. The highest score of the standard deviation $\sim 1.04$ suggests that some of the respondents do not see that much benefit in the information based on location, compared to the other benefits of m-commerce. 
A step that needs to be taken to guarantee the validity and accuracy of the interpretation of the data is the implementation of the Cronbach's alpha test. This test is usually used to measure the internal consistency of a test or scale and is expressed as a number between 0 and 1 (Tavakol \& Dennick, 2011). After running the test for the seven questions above, the result of $\alpha=0.934$ shows highly consistent data (an acceptable range from 0.70 to 0.95 ).

Table 7

Perceived benefits of mobile commerce

\begin{tabular}{|c|c|c|}
\hline Statements: & Mean & Std. deviation \\
\hline I can use it anywhere. & 4.2787 & 1.00645 \\
\hline I can use it anytime. & 4.3240 & 0.95138 \\
\hline It is convenient. & 4.1010 & 1.03449 \\
\hline It is enjoyable. & 3.9721 & 0.93826 \\
\hline It provides me with a rapid response. & 3.9129 & 0.95130 \\
\hline Information based on location. & 3.8780 & 1.03561 \\
\hline It is beneficial. & 3.9094 & 0.97458 \\
\hline
\end{tabular}

\subsection{Perceived Benefits and Number of M-Transactions}

By applying ANOVAs, the perceived benefits were also examined in relation to the number of $\mathrm{m}$-transactions. The results (Table 8 ) revealed that with the exception of the use-anywhere opportunity, all benefits are greatly influenced by the number of $m$-transactions. Therefore, adopters who utilize m-commerce to a greater extent get much more advantages of mobile technology.

Table 8

Perceived benefits of mobile commerce in relation to the number of $\mathrm{m}$-transactions

\begin{tabular}{|c|c|c|}
\hline Statements: & F value & Sig. \\
\hline I can use it anywhere. & 1.858 & 0.102 \\
\hline I can use it anytime. & 4.147 & 0.001 \\
\hline It is convenient. & 2.980 & 0.012 \\
\hline It is enjoyable. & 4.741 & 0.0 \\
\hline It provides me with a rapid response. & 2.493 & 0.031 \\
\hline Information based on location. & 4.332 & 0.001 \\
\hline It is beneficial. & 2.525 & 0.030 \\
\hline
\end{tabular}

\subsection{M-Commerce Attitudes of Undergraduate and Postgraduate University Students}

Furthermore, it is important to understand the students' attitudes toward m-commerce, as positive attitudes can lead to the $\mathrm{m}$-commerce adoption and negative attitude to the $\mathrm{m}$-commerce denial. This research concludes that both undergraduate and postgraduate students are positive about $\mathrm{m}$-commerce and it seems as a good idea to them (mean 4.00) (Table 9).

The subjective norm can help understand if students are influenced by their surroundings in the decision to be part of $\mathrm{m}$-commerce. Both undergraduate and postgraduate students disagree with the statement that they would shop with a smartphone because their friends do so. They also state that no one in their surroundings is responsible for their decision to be part of $\mathrm{m}$-commerce. 
Furthermore, no difference in the opinions of undergraduate and postgraduate students when it comes to trust was found. They mostly hold from a neutral to negative position when it comes to perceptions of confidentiality of personal data. When it comes to trust in the payments and monetary transactions, undergraduates and postgraduates feel safe, even though there is a certain hesitation. Meanwhile, undergraduates are more positive than postgraduates when it comes to the perception that the terms of use are strictly followed while using m-services. Additionally, no t-test revealed statistically differences between undergraduate and postgraduate students.

Table 9

Satisfaction with m-commerce and future intentions to use it - Education level

\begin{tabular}{|c|c|c|c|c|c|c|}
\hline Variable & Questions & Education level & Mean & Deviation & $\begin{array}{l}\text { Std error } \\
\text { mean }\end{array}$ & t-test value \\
\hline \multirow{4}{*}{ Attitude } & \multirow{2}{*}{$\begin{array}{l}\text { I am positive about mobile } \\
\text { shopping. }\end{array}$} & Undergraduate & 4.000 & 0.786 & 0.079 & \multirow{2}{*}{0.10} \\
\hline & & Postgraduate & 3.989 & 0.869 & 0.063 & \\
\hline & \multirow{2}{*}{$\begin{array}{l}\text { Shopping via a mobile } \\
\text { is a good idea. }\end{array}$} & Undergraduate & 4.000 & 0.862 & 0.087 & \multirow{2}{*}{0.0} \\
\hline & & Postgraduate & 4.000 & 0.899 & 0.065 & \\
\hline \multirow{4}{*}{$\begin{array}{l}\text { Subjective } \\
\text { norm }\end{array}$} & \multirow{2}{*}{$\begin{array}{l}\text { I would shop with a smartphone } \\
\text { because my friends do so. }\end{array}$} & Undergraduate & 2.939 & 1.156 & 0.117 & \multirow{2}{*}{-0.24} \\
\hline & & Postgraduate & 2.974 & 1.173 & 0.085 & \\
\hline & \multirow{2}{*}{$\begin{array}{l}\text { People who are important } \\
\text { to me think I should use mobile } \\
\text { shopping. }\end{array}$} & Undergraduate & 2.949 & 1.205 & 0.122 & \multirow[b]{2}{*}{-0.14} \\
\hline & & Postgraduate & 2.968 & 1.081 & 0.079 & \\
\hline \multirow{6}{*}{ Trust } & \multirow{2}{*}{$\begin{array}{l}\text { I feel my personal data are } \\
\text { in confidence while using } \\
\text { m-services. }\end{array}$} & Undergraduate & 3.143 & 1.103 & 0.111 & \multirow[b]{2}{*}{-0.31} \\
\hline & & Postgraduate & 3.185 & 1.098 & 0.080 & \\
\hline & \multirow{2}{*}{$\begin{array}{l}\text { I feel using m-services in } \\
\text { monetary transactions is safe. }\end{array}$} & Undergraduate & 3.337 & 0.973 & 0.098 & \multirow{2}{*}{0.76} \\
\hline & & Postgraduate & 3.238 & 1.082 & 0.079 & \\
\hline & \multirow{2}{*}{$\begin{array}{l}\text { I feel the terms of use are strictly } \\
\text { followed while using m-services. }\end{array}$} & Undergraduate & 3.531 & 0.864 & 0.087 & \multirow{2}{*}{1.38} \\
\hline & & Postgraduate & 3.365 & 1.015 & 0.074 & \\
\hline
\end{tabular}

The research aimed to compare undergraduate and postgraduate students at the gender level and their satisfaction with the m-commerce usage. Consequently, it was concluded that most of the respondents are satisfied with m-commerce and the students are ready to switch from laptop, desktop computer, etc., to smartphone usage. As satisfaction is at a high level and the students have already started to shift their preferences to smartphones/tablets as a preferred technology to use, it is no wonder that most respondents have the intentions to continue shopping via their mobile phones and tablets (Figure 2). 
Figure 2

Intentions to use m-commerce in the future

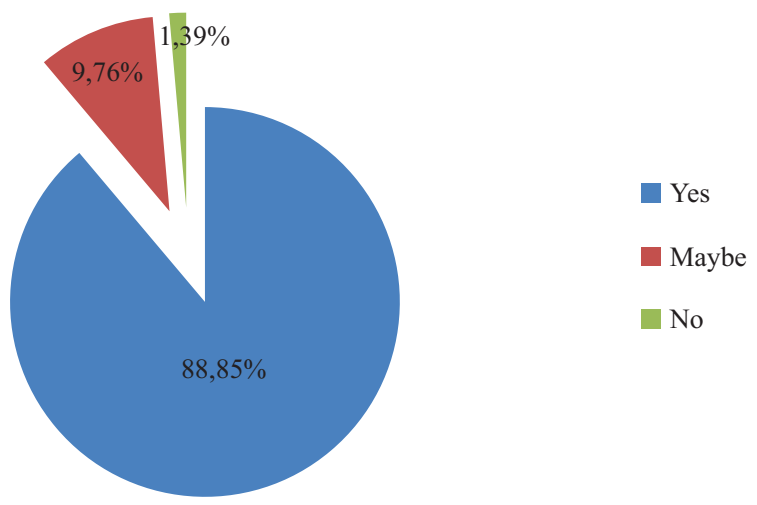

\subsection{M-Commerce Attitudes of Males and Females}

Furthermore, we tested the m-commerce attitude questionnaire items again in order to reveal possible differences between males and females (Table 10). With the exception of two out of three trust questions, no statistical differences were revealed. However, males perceived that money transactions in the m-commerce environment are more trustworthy compared to females. The same results came up regarding the perceived terms of use followed in m-services. Based on the aforementioned information, we allege that males in Bulgaria are much more receptive to m-services as trust issues are of great concern and one of the most important factors of the adoption and level of m-commerce use.

Table 10

Satisfaction with m-commerce and future intentions to use it - Gender

\begin{tabular}{|c|c|c|c|c|c|c|}
\hline Variable & Questions & Gender & Mean & Deviation & $\begin{array}{l}\text { Std error } \\
\text { mean }\end{array}$ & t-test value \\
\hline \multirow{4}{*}{ Attitude } & \multirow{2}{*}{ I am positive about mobile shopping. } & Male & 4.05 & 0.80 & 0.075 & \multirow{2}{*}{0.98} \\
\hline & & Female & 3.95 & 0.87 & 0.066 & \\
\hline & \multirow{2}{*}{$\begin{array}{l}\text { Shopping via a mobile is a good } \\
\text { idea. }\end{array}$} & Male & 4.05 & 0.85 & 0.079 & \multirow{2}{*}{0.82} \\
\hline & & Female & 3.95 & 0.91 & 0.069 & \\
\hline \multirow{4}{*}{$\begin{array}{l}\text { Subjective } \\
\text { norm }\end{array}$} & \multirow{2}{*}{$\begin{array}{l}\text { I would shop with a smartphone } \\
\text { because my friends do so. }\end{array}$} & Male & 2.94 & 1.24 & 0.117 & \multirow{2}{*}{-0.27} \\
\hline & & Female & 2.98 & 1.11 & 0.085 & \\
\hline & \multirow{2}{*}{$\begin{array}{l}\text { People who are important to me } \\
\text { think I should use mobile shopping. }\end{array}$} & Male & 3.07 & 1.19 & 0.111 & \multirow{2}{*}{1.33} \\
\hline & & Female & 2.89 & 1.08 & 0.082 & \\
\hline \multirow{6}{*}{ Trust } & \multirow{2}{*}{$\begin{array}{l}\text { I feel my personal data are in } \\
\text { confidence while using m-services. }\end{array}$} & Male & 3.46 & 1.09 & 0.102 & \multirow{2}{*}{1.49} \\
\hline & & Female & 3.14 & 1.10 & 0.083 & \\
\hline & \multirow{2}{*}{$\begin{array}{l}\text { I feel using m-services in monetary } \\
\text { transactions is safe. }\end{array}$} & Male & 3.56 & 1.00 & 0.094 & \multirow{2}{*}{2.56} \\
\hline & & Female & 3.33 & 1.06 & 0.080 & \\
\hline & \multirow{2}{*}{$\begin{array}{l}\text { I feel the terms of use are strictly } \\
\text { followed while using m-services. }\end{array}$} & Male & 3.531 & 0.96 & 0.089 & \multirow{2}{*}{2.00} \\
\hline & & Female & 3.365 & 0.97 & 0.073 & \\
\hline
\end{tabular}




\section{CONCLUSIONS}

The research leads to the conclusion that Bulgarian students have adopted the use of smartphones and tablets and use them for different purposes. It also becomes clear that most of non-adopters of $\mathrm{m}$-commerce have intentions to start using m-commerce in a near future. Moreover, it was found that more people with higher education buy via hand-held devices as shopping "anytime, anyplace" is really convenient for them. Another conclusion is that students in Bulgaria are new adopters of m-commerce and most of them have used it for a year or two. Last but not least, the more m-transactions students conduct, the more the perceived benefits of the m-commerce technology.

Meanwhile, males and females, regardless of whether they are undergraduates or postgraduates, spend similar amounts of money and make similar numbers of transactions. The products and services which are mostly bought by students are clothing, apparel and accessories. On the contrary, they do not have much trust in insurance and financial services yet.

The respondents state that $\mathrm{m}$-commerce is time-efficient, easy to access and easy to use. Another advantage for male students is the perceived low cost. However, the results show that women find $\mathrm{m}$-commerce more expensive than men. On the other hand, male students seem to trust m-commerce transactions to a greater extent than female ones. Also, students are fond of communication when being part of m-commerce. Hence, students believe that the process from a purchase request to the final step is coordinated and communicated by the seller. A drawback of m-commerce is the lack of social contact. If more businesses work on their platforms and provide a channel of communication between their customers where they can share opinions, this perception might change.

One of the strongest motivators for the students is the fact that they can use m-commerce anywhere and anytime. They claim its convenience, enjoyment and benefits. An interesting finding is that respondents do not see that much benefit from information based on location, compared to the other benefits of m-commerce. Obviously, there is a gap in the market that prevents students from seeing the convenience and profit from location-based information. Being aware of the location of the user is a significant advantage for $\mathrm{m}$-commerce over wired e-commerce as it can help businesses better receive and send information relevant to a specific location (Mahatanankoon et al., 2005); businesses need to make sure that they take advantage of it.

The attitude toward $\mathrm{m}$-commerce has emerged as a strong predictor of its adoption. Also, the research confirms that there is a significant correlation between trust and behavioral intentions of the user and trust is a factor that can predict the m-commerce adoption. Both undergraduates and postgraduates trust their monetary transactions to be safe, even though they are afraid about their personal data. This survey has found that the subjective norm has no influence on the Bulgarian students' decision making and the process of m-commerce adoption. An explanation can be found in the specific Bulgarian mentality and way of thinking as Bulgarians are a very proud nation with specific understandings (Tzvetkova, 2015). This could be considered as a drawback for the m-commerce adoption, as the subjective norm and positive comments from others might lead to/ foster the m-commerce adoption.

To summarize, undergraduate and postgraduate students are mostly satisfied with the $\mathrm{m}$-commerce transactions that they have previously made. The fact that satisfaction is at a high level in the perception of Bulgarian students and the students' readiness to switch from laptops to hand-held devices can surely lead to better future adoption. Admittedly, this research can be of great value to the business and academic world as it shows that Bulgarian students are ready to switch from e-commerce to m-commerce. Inevitably, companies' strategies need to be adapted to the current situation on the market. 


\section{Recommendations and Limitations}

Many questions concerning $\mathrm{m}$-commerce adopters in Bulgaria and higher education students in particular were answered. However, a suggestion for further research could be to mix quantitative and qualitative research and to include not only simple statistics like t-tests, chi-squares and ANOVAs. Administering the same questionnaire in another country and making a cross-country analysis is also a very good opportunity for comparisons. Also, future research should aim for no restrictions on respondents to select a more diverse sample and draw more general conclusions.

Furthermore, other factors-predictors of m-commerce adoption such as anxiety about the use of technology and perceived behavioral control can be included for a more complete and consistent analysis. Another part which can be further investigated is a group of respondents who are not $\mathrm{m}$-commerce adopters. They can be also included in future studies. If the reasons for not being part of $\mathrm{m}$-commerce are evaluated, then the industry and the academia will have much to elaborate on. Emphasizing specific cultural characteristics of Bulgarians for better reliability and certainty can also lead to significant findings.

\section{References}

Agrebia, S. \& Jallaisb, J. (2015). Explain the intention to use smartphones for mobile shopping. Journal of Retailing and Consumer Services, 22(1), 16-23. https://doi.org/10.1016/j.jretconser.2014.09.003

Anderson, M. (2015). The demographics of device ownership. Pew Research Center Internet, Science \& Tech. Retrieved from http://www.pewinternet.org/2015/10/29/the-demographics-of-device-ownership/ (21 April 2017).

Chaffey, D. (2017). Mobile marketing statistics 2017. Smart Insights. Retrieved from http://www.smartinsights.com/ mobile-marketing/mobile-marketing-analytics/mobile-marketing-statistics/ (28 Mar. 2017).

Chang, J.M., Williams, J. \& Hurlburt, F.G. (2014). Mobile commerce. IT Professional, 16(3), 4-5. https://doi. org/10.1109/MITP.2014.36

Chen, Y., Yan, X., Fan, W., \& Gordon, M. (2015). The joint moderating role of trust propensity and gender on consumers' online shopping behavior. Computers in Human Behavior, 43(1), 272-283. https://doi. org/10.1016/j.chb.2014.10.020

Chong, A. (2013). Mobile commerce usage activities: The roles of demographic and motivation variables. Technological Forecasting and Social Change, 80(7), 1350-1359. https://doi.org/10.1016/j.techfore.2012.12.011

Chong, A. (2013). Predicting m-commerce adoption determinants: A neural network approach. Expert Systems with Applications, 40(2), 523-530. https://doi.org/10.1016/j.eswa.2012.07.068

Ciprian, P. \& Vlad, F. (2016). Trends in the evolution of mobile commerce.

Davis, F. (1989). Perceived usefulness, perceived ease of use and user acceptance of information technology. MIS Quarterly, 13, 319-340. https://doi.org/10.2307/249008

Dužević, I., Delić, M., \& Knežević, B. (2016). Customer satisfaction and loyalty factors of Mobile Commerce among young retail customers in Croatia. Gestão e Sociedade, 10(27), 1476. https://doi.org/10.21171/ges. v10i27.2129

Eastin, M.S., Brinson, N.H., Doorey, A., \& Wilcox, G. (2016). Living in a big data world: Predicting mobile commerce activity through privacy concerns. Computers in Human Behavior, 58, 214-220. https://doi. org/10.1016/j.chb.2015.12.050

Ecommerce News. (2016). Mobile shopping behaviors in Europe. Retrieved from https://ecommercenews.eu/mobileshopping-behaviors-europe/ (22 Aug. 2017).

Eurostat.com. (2016). Tables, Graphs and Maps Interface (TGM) table. Individuals using mobile devices to access the internet on the move. Ec.europa.eu. Retrieved from http://ec.europa.eu/eurostat/tgm/refreshTableAction. do? tab $=$ table \&plugin $=1 \&$ p code $=$ tin00083\&language $=$ en $(16$ Feb. 2017).

Faqih, K. \& Jaradat, M. (2015). Assessing the moderating effect of gender differences and individualism-collectivism at individual-level on the adoption of mobile commerce technology: TAM3 perspective. Journal of Retailing and Consumer Services, 22, 37-52. https://doi.org/10.1016/j.jretconser.2014.09.006

Gao, Y., Li, L., \& Yang, Y. (2014). Application of smart phone in mobile commerce and development tendency. Information Technology Journal, 13(6), 1054-1061. https://doi.org/10.3923/itj.2014.1054.1061 
Georgiadis, C.K. \& Stergiopoulou, S.H. (2008). Mobile commerce application development: Implementing personalized services. 7th International Conference on Mobile Business, 201-210. https://doi.org/10.1109/ ICMB.2008.35

Grigorova, K. (2015). Growth in mobile commerce and online sales.

Hillman, S. \& Neustaedter, C. (2017). Trust and mobile commerce in North America. Computers in Human Behavior, 70, 10-21. https://doi.org/10.1016/j.chb.2016.12.061

Hitt, L. \& Frei, F. (2002). Do better customers utilize electronic distribution channels? The case of PC banking. Management Science, 48(6), 732-748. https://doi.org/10.1287/mnsc.48.6.732.188

Hsi-Peng, L. \& Su, P. (2009). Factors affecting purchase intention on mobile shopping web sites. Internet Research, 19(4), 442-458. https://doi.org/10.1108/10662240910981399

IAB (Interactive Advertising Bureau). (2014). VI study IAB Spain about mobile marketing. Retrieved from www. iabspainnet/wp-content/uploads/downloads/2014/09/VI_Estudio_Anual_Mobile_Marketing_ve rsion_ abierta1.pdf (19 Aug. 2017).

Jimenez, N., San-Martin, S., \& Azuela, J.I. (2016). Trust and satisfaction: The keys to client loyalty in mobile commerce. Academia Revista Latinoamericana de Administración, 29(4), 486-510. https://doi.org/10.1108/ ARLA-12-2014-0213

Khare, A. \& Sadachar, A. (2014). Collective self-esteem and online shopping attitudes among college students: Comparison between the U.S. and India. Journal of International Consumer Marketing, 26(2), 106-121. https://doi.org/10.1080/08961530.2014.878203

Lancaster, H. (2016). Bulgaria - Mobile infrastructure, broadband, operators - Statistics and analyses. Budde. com.au. Retrieved from https://www.budde.com.au/Research/Bulgaria-Mobile-Infrastructure-BroadbandOperators-Statistics-and-Analyses (16 Feb. 2017).

Liang, T.P. \& Wei, C.P. (2004). Introduction to the special issue: Mobile commerce applications. International Journal of Electronic Commerce, 8(3), 7-17. https://doi.org/10.1080/10864415.2004.11044303

Lu, H. \& Su, P. (2009). Factors affecting purchase intention on mobile shopping web sites. Internet Research, 19(4), 442-=458. https://doi.org/10.1108/10662240910981399

Mahatanankoon, P., Wen, H. J., \& Lim, B. (2005). Consumer-based m-commerce: Exploring consumer perception of mobile applications. Computer Standards \& Interfaces, 27(4), 347-357. https://doi.org/10.1016/j. csi.2004.10.003

Maity, M. \& Dass, M. (2014). Consumer decision-making across modern and traditional channels: E-commerce, m-commerce, in-store. Decision Support Systems, 61, 34-46. https://doi.org/10.1016/j.dss.2014.01.008

Meola, A. (2017). The rise of m-commerce: Mobile shopping stats \& trends. Business Insider. Retrieved from http:// www.businessinsider.com/mobile-commerce-shopping-trends-stats-2016-10 (22 Feb. 2017).

Min, Q., Ji, S., \& Qu, G. (2008). Mobile commerce user acceptance study in China: A revised UTAUT model. Tsinghua Science \& Technology, 13(3), 257-264. https://doi.org/10.1016/S1007-0214(08)70042-7

Narang, B. \& Arora, J. (2016). Present and future of mobile commerce: Introduction, comparative analysis of $\mathrm{m}$ commerce and e commerce, advantages, present and future. In S. Madan \& J. Baatra Arora, Securing transactions and payment systems for m-commerce (pp. 1-16). IGI Global. https://doi.org/10.4018/978-15225-0236-4.ch015

Nassuora, A. (2013). Understanding factors affecting the adoption of m-commerce by consumers. Journal of Applied Sciences, 13(6), 913-918. https://doi.org/10.3923/jas.2013.913.918

OECD. (2013) Electronic and mobile commerce. OECD Digital Economy Papers, (228). Paris: OECD Publishing. Retrieved from http://dx.doi.org/10.1787/5k437p2gxw6g-en (16 Feb. 2017). https://doi. org/10.1787/5k437p2gxw6g-en

Patil, P. (2017). Technological advancements and its impact on humanity. Academia.edu. Retrieved from http://www. academia.edu/346486/Technological_Advancements_and_Its_Imp act_on_Humanity (22 Aug. 2017).

Ratcliff, Ch. (2015). 10 of the finest mobile ecommerce sites. Econsultancy. Retrieved from https://econsultancy. com/blog/66647-10-of-the-finest-mobile-ecommerce-sites/ (14 Jun. 2017).

Rhee, K. \& Kim, W. (2004). The adoption and use of the Internet in South Korea. Journal of Computer-Mediated Communication, 9(4). https://doi.org/10.1111/j.1083-6101.2004.tb00299.x

San-Martín, S., Prodanova, J., \& López Catalán, B. (2016). What makes services customers say "buy it with a mobile phone"? Journal of Services Marketing, 30(6), 601-614. https://doi.org/10.1108/JSM-02-2015-0081

Saprikis, V. (2013). A longitudinal investigation on Greek University students' perceptions toward online shopping. Journal of Electronic Commerce in Organizations, 11(1), 43-62. https://doi.org/10.4018/jeco.2013010103

Saritas, O., Gokhberg, L., Bakhtin, P., \& Kuzminov, I. (2016). Weak signals on the future of mobile commerce in Russia. National Research University of Higher School of Economic Research Paper Series, 1-17. https:// doi.org/10.2139/ssrn.2857108

Shang, D. \& Wu, W. (2017). Understanding mobile shopping consumers' continuance intention. Industrial Management \& Data Systems, 117(1), 213-227. https://doi.org/10.1108/IMDS-02-2016-0052 
Shead, W., Derevensky, J., Fong, T., \& Gupta, R. (2012). Characteristics of internet gamblers among a sample of students at a large, public University in Southwestern United States. Journal of College Student Development, 53(1), 133-148. https://doi.org/10.1353/csd.2012.0005

Statista.com. (2016). Connected device usage rate in Bulgaria from 2014 to 2016, by device. Statista Online Database. Retrieved from https://www.statista.com/statistics/346669/connected-device-usage-bulgaria/ (15 Feb. 2017).

Tairov, I.L. (2014). Mobile commerce and its' problems. Computerworld, (1), 96-109. Retrieved from http:// computerworld.bg/47198_samo_rast_pri_mobilnata_targoviya_i_onlajn_prodazhbite (19 Sep. 2017).

Tavakol, M. \& Dennick, R. (2011). Making sense of Cronbach's alpha. International Journal of Medical Education, 2, 53-55. https://doi.org/10.5116/ijme.4dfb.8dfd

Tzvetkova, J. (2015). Bulgaria - Culture smart!: The essential guide to customs \& culture. London: Kuperard.

UNESCO UIS. (2017). ISCED fields of education and training 2013 (ISCED-F 2013). Retrieved from http://www. uis.unesco.org/Education/Documents/isced-fields-of-education-training-2013.pdf (17 Jun. 2017).

Venkatesh, V., Morris, M.G., Davis, G.B., \& Davis, F.D. (2003). User acceptance of information technology: Toward a unified view. MIS Qarterly, 27(3), 425-478. https://doi.org/10.2307/30036540

Wang, R.J., Malthouse, E.C., \& Krishnamurthi, L. (2015). On the go: How mobile shopping affects customer purchase behavior. Journal of Retailing, 91(2), 217-234. https://doi.org/10.1016/j.jretai.2015.01.002

Yadav, R., Sharma, S.K., \& Tarhini, A. (2016). A multi-analytical approach to understand and predict the mobile commerce adoption. Journal of Enterprise Information Management, 29(2), 222-237. https://doi.org/10.1108/ JEIM-04-2015-0034

Yang, K. (2012). Consumer technology traits in determining mobile shopping adoption: An application of the extended theory of planned behavior. Journal of Retailing and Consumer Services, 19(50), 484-491. https:// doi.org/10.1016/j.jretconser.2012.06.003

Zarmpou, T., Saprikis, V., Vlachopoulou, M., \& Tsiotsou, R. (2010). Predicting the adoption of mobile transactions: An exploratory investigation in Greece.

Zhang, J., Liu, Y., \& Nie, L. (2009). A review for the risks and challenges of mobile commerce development. International Conference on E-Business and Information System Security, 1-4. https://doi.org/10.1109/ EBISS.2009.5137895

Zhang, L., Zhu, J, \& Liu, Q. (2012). A meta-analysis of mobile commerce adoption and the moderating effect of culture. Computers in Human Behavior, 28(5), 1902-1911. https://doi.org/10.1016/j.chb.2012.05.008

Zickuhr, K. (2013) Tablet ownership 2013. Research Center Internet, Science \& Tech. Retrieved from http://www. pewinternet.org/files/old-media/Files/Reports/2013/PIP_Tablet\%20ownership\%202013.pdf (21 April 2017). 